\title{
ANALYSIS OF THE AMOUNT OF PRODUCTION AND INCOME OF THE FARMERS OF PINEAPPLE INTERCROPPING PLANTS OF TANJUNG MEDANG VILLAGE, MUARA ENIM DISTRICT
}

\author{
Mulyana Eka, Researcher \\ University of Sriwijaya, Indonesia \\ E-mail: eka.agri@gmail.com
}

\begin{abstract}
This study aimed to analyze the amount of production and farming income of pineapple intercropping plants of Tanjung Medang Village, Muara Enim District. It was conducted in Tanjung Medang Village, Muara Enim District. The data were collected in the location in May 2018. The survey method was used. The sampling technique was a simple random sampling by taking 34 respondents out of 148 farmers of pineapple intercropping plants. The collected data were primary and secondary data. The results of the study showed that the average amount of production of pineapple intercrops was 24,547 pieces $/ \mathrm{lg} / \mathrm{mt}$. The average income of the farmers obtained from the pineapple intercropping was IDR 42,552,070, $-/ \mathrm{lg} / \mathrm{mt}$.
\end{abstract}

\section{KEY WORDS}

Pineapple intercroping, production, income, intercrops.

Plantations are one of the important agricultural sub-sectors because they have a significant contribution to the Indonesian economy. One of the most important plantation crops in Indonesia is rubber since it supports many of Indonesia's economy. The rubber plantation business is mostly cultivated by the people up to $85 \%$ of the total plantations cultivated by the state and the private sectors. According to the data of the Directorate General of Plantations (2016), most of Indonesia's rubber plantation areas are located in Sumatra (70\%), Kalimantan (24\%), and Java (4\%).

South Sumatra Province has the largest rubber plantation in Indonesia and absorbs a much larger workforce than any other commodity does. The total area of rubber cultivation is 841,252 hectares and the number of rubber farmers is 464,541 householders. The total area consists of Unprocessed Crops (UC) covering 114,353 Ha, Produced Crops (PC) covering $710,174 \mathrm{Ha}$, and Old Crops (OC) covering 16,724 Ha. During the UC period, South Sumatra itself has a quite extensive area of rubber plantations to be optimized for the rubber farmers' additional income during the waiting period. One of the many ways to do it is intercropping. Intercropping can be an alternative income during the waiting period for farmers who do not have other income apart from the rubber. In addition to providing additional income for farmers during the waiting period for rubber plants to produce, intercrops can also provide direct benefits to rubber plants. Rosyid (2007) conducted a study that intercrops could have a positive effect on rubber growth in the rejuvenation area of Sarolangun District of Jambi. Using a monoculture cropping pattern caused seasonal unemployment, where the farmers did not have work between the UC and PC periods. One of the intercropping plants grown by the farmers was pineapple.

Pineapple (Ananas comosus L.) is one of the leading fruit commodities in Indonesia. It refers to the amount of pineapple production which is the third position after that of bananas and mangoes. Besides being consumed fresh, pineapples can also be processed into various products such as juice, jam, syrup and chips. They contain elements of water, sugar, organic acids, minerals, nitrogen, protein, bromelin and all vitamins in small amounts, except vitamin D. Pineapple peel can be processed into syrup or extracted liquid for animal feed, while the fiber in the leaves can be processed into paper and textiles (Hadiati and Indriyani, 2008)..

Kelekar Subdistrict is one of the subdistricts of Muara Enim District where rubber farmers cultivate intercrops among unprocessed rubber plants, especially in Tanjung 
Medang Village. The area of pineapple plantations in Kelekar Subdistrict is 80 hectares with a production of $3,443.50$ tons. This causes the land area used for pineapple farming to be less extensive than that of rubber plantation. According to the local villagers, pineapple intercropping of Tanjung Medang Village has existed since 1971. At the beginning of the pineapple intercropping, there were very few farmers cultivating it because the cost and lack of knowledge of farmers on intercropping pineapple cultivation. Based on the description above, the author was interested in studying how much production and income was earned from the intercropping pineapple farming in Tanjung Medang Village, Muara Enim District.

\section{METHODS OF RESEARCH}

Place and Time of the Study. This research was conducted in the village of Tanjung Medang, Kelekar Subdistrict of Muara Enim District. The location was selected on purposive based on the consideration that Tanjung Medang Village was one of the villages in Muara Enim District planting intercropping pineapple among unprocessed rubber plants. The study was carried out from May 2018 to completion.

The study used a survey method and simple random sampling, considering that each member of the population had the same chance to be selected sample and they were homogeneous or had an similar character (Suharso, 2012). The number of sample was determined by using Slovin formulas (Sriati, 2013) as follows:

$$
\mathrm{n}=\frac{\mathrm{N}}{1+\mathrm{N} \cdot \mathrm{e}^{2}}=\frac{148}{1+148(0,15)^{2}}=34 \cdot 18014 \text { (34 people) }
$$

The collected data were primary and secondary data. The primary data were obtained through survey results and direct interviews with farmer samples using questionnaires. The secondary data were obtained from the literature study such as books, articles, and previous research results related to this study. The data were then analyzed mathematically, presented in tabulation, and explained descriptively. The data were analysed using Microsoft Excel 2013 computer application.

The findings on the amount of the pineapple intercropping production are presented in tabulation and explained descriptively based on the data obtained from the field. To calculate the amount of farmers' income, the following formula is used (Sjarkowi and Sufri, 2004):

$$
P d_{u}=P n_{u}-B T_{u}
$$

Where: Pdu $=$ Farmer's income in the cultivation of pineapple $($ IDR/lg/mt); Pnu $=$ Revenue (IDR/lg/mt); BTu = The total cost of pineapple intercropping (IDR/lg/mt).

\section{RESULTS AND DISCUSSION}

The production of pineapple intercropping was carried out with a variety of farming activities such as seed selection, land preparation, planting, plant maintenance, fertilization, pest control and plant diseases, carbide use, and harvesting. The output produced from pineapple intercrops was fresh pineapple. The production calculated was the yield of one planting season, meaning that the yield occurred three times in one planting season in a period of approximately two years. The average production amount obtained by the sample farmers in one planting season was 24,547 pieces / lg.

Pineapple crop production costs were calculated from the costs incurred by farmers during one planting season. They consisted of fixed costs and variable costs. The incurred fixed costs were hand sprayers, tengkuit (a grass cutting tool) and machetes. Meanwhile, the variable costs incurred included the use of pineapple seeds, fertilizer, pesticides, land rent, carbide and labor during land preparation, planting, and carbide use. This production cost was calculated based on the price multiplied by each number of factors of production. The price was determined by the owner of the production factor. 
Table 1 - Average Total Cost of Production of Pineapple Crops in Tanjung Medang Village

\begin{tabular}{ccc}
\hline No & Item & Total (IDR/lg/mt) \\
\hline 1 & Fixed Cost & 298,239 \\
2 & Variable Cost & $5,021,456$ \\
\hline & Grand Total & $5,319,695$ \\
\hline
\end{tabular}

The above data shows that the total cost of production of pineapple crop farming is $\mathrm{Rp}$ $5,120,869,-/ / \mathrm{g} / \mathrm{mt}$. The costs incurred in this farming were the variable costs of $\mathrm{Rp}$ $5,021,456,-/ \mathrm{lg} / \mathrm{mt}$ while the fixed costs are Rp 99,413, - / $/ \mathrm{g} / \mathrm{mt}$. The variable costs were spent more because pineapple intercrops among unprocessed rubber required greater use of fertilizers, pesticides, carbides, land rent and labor costs.

The details of the average fixed costs incurred by pineapple farmers is presented in Table 2 as follows:

Table 2 - Average Fixed Cost of Variable of Pineapple Intercropping Farming in Tanjung Medang Village

\begin{tabular}{ccc}
\hline No & Fixed Cost & Total (IDR/Lg/MT) \\
\hline 1 & Hand Sprayer & 133,472 \\
2 & Tengkuit & 63,208 \\
3 & Machete & 101,560 \\
\hline & Grand Total & 298,239 \\
\hline
\end{tabular}

Table 2 shows that the average fixed costs of pineapple intercropping farming was IDR $298,239,-$ / lg / mt. The average cost of handsprayer was IDR 133,472, - / /mt. The sample farmers usually used manual handsprayers. The average cost of tengkuit was IDR 63,208 ,$/ \mathrm{lg} / \mathrm{mt}$. The average cost of machetes spent by the farmers was IDR $101,560,-/ \mathrm{lg} / \mathrm{mt}$. While the average variable costs incurred by pineapple intercropping crop farmers is given in the table below.

Table 3 - Average Fixed Cost of Variable of Pineapple Intercropping Farming in Tanjung Medang Village

\begin{tabular}{ccc}
\hline No & Variable Cost & Total (IDR/lg/mt) \\
\hline 1 & Seed & 919,118 \\
2 & Fertilizers & $2,200,618$ \\
3. & Pesticides & 184,765 \\
4 & Land Rentals & 867,647 \\
5 & Carbide & 110,485 \\
6 & Labor & 738,824 \\
\hline
\end{tabular}

Table 3 above shows that the total cost of variable of pineapple intercropping was $\mathrm{Rp}$. $5,021,456,-/ \mathrm{lg} / \mathrm{mt}$. The variable costs were derived from the ones for nurseries, fertilizers (organic fertilizers, urea fertilizers, NPK fertilizers, and phonska fertilizers), pesticides, land rent, carbide, and labor. A lot of variable costs were spent on fertilizer as much as IDR $2,200,618,-/ \mathrm{kg} / \mathrm{mt}$ and seeds as much as IDR 919,118,- $/ \mathrm{lg} / \mathrm{mt}$. It resulted from the price of chemical fertilizers such as urea, NPK, and phonska which was more expensive than any other variable costs. The average price of urea fertilizer was IDR $124,536,-$ per sack of $50 \mathrm{~kg}$, the price depended on the type of urea; the white urea was IDR 250,000,- /sack, the red urea was IDR 120,000 ,- /sack. The NPK fertilizer cost ranged from IDR 250,000,- to IDR 500,000,/sack. A sack of NPK fertilizer weighed $50 \mathrm{~kg}$. Meanwhile, the average Phonska fertilizer cost about IDR $124,536 /$ sack of $50 \mathrm{~kg}$.

Revenue of Pineapple Intercropping Farming. The revenue of pineapple intercropping farming was in accordance with the production for one planting season which was three times, as well as based on the prices set by the middlemen as the buyers of the pineapples. Table 4 shows the average income obtained by the farmers from the pineapple intercropping 
farming for three harvests for IDR $47,476,484,-/ \mathrm{kg} / \mathrm{mt}$ with an average price of IDR 1,945.100.- per piece.

Table 4 - Average Revenue of Pineapple Intercropping Farming in Tanjung Medang Village

\begin{tabular}{ccc}
\hline No & Items & Total \\
\hline 1 & Production Amount (piece/lg/mt) & 24,547 \\
& Harvest 1 & 8,876 \\
& Harvest 2 & 8,471 \\
2 & Harvest 3 & 7,200 \\
& Price (IDR/piece/lg/mt) & $1,945.100$ \\
& Harvest 1 & $2,701.47$ \\
& Harvest 2 & $1,992.650$ \\
& Harvest 3 & $1,141.180$ \\
\hline
\end{tabular}

Income of Pineapple Intercropping Farming. Based on the data above, the average yield of pineapple intercropping production amounted to $24,547 / \mathrm{piece} / \mathrm{lg} / \mathrm{mt}$ with the average price of a pineapple was IDR $1,950.204,-/ \mathrm{lg} / \mathrm{mt}$. The total production cost was Rp $5,319,695,-/ \mathrm{kg} / \mathrm{mt}$ and the farmer's income for three harvests was IDR $47,871,765,-/ \mathrm{kg} / \mathrm{mt}$ so that the farmers' income was Rp. 42,552,070,- /lg/mt.

Table 5 - Average Revenue of Pineapple Intercropping Farming in Tanjung Medang Village

\begin{tabular}{|c|c|c|}
\hline No & Item & Total \\
\hline 1 & Average amount of pineapple intercropping production (piece/lg/mt) & 24.547 \\
\hline 2 & Price (IDR/piece/lg/mt) & $1,945.100$ \\
\hline 2 & Revenue (IDR/lg/mt) & $47,746,484$ \\
\hline 3 & Production Total Cost (IDR/lg/mt) & $5,319,695$ \\
\hline & Revenue (IDR/lg/mt) & $42,552,070$ \\
\hline
\end{tabular}

\section{CONCLUSION}

The average amount of production obtained by the sample farmers in pineapple intercropping farming was IDR $24.547 / \mathrm{piece} / \mathrm{kg} / \mathrm{mt}$, and the average income of the pineapple intercropping farmers was IDR 42,552,070, - /lg/mt.

\section{REFERENCES}

1. Badan Pusat Statistik Kecamatan Inderalaya Selatan.2017. Kecamatan Inderalaya Selatan dalam Angka 2017 [online].http;//sumsel.bps.go.id/beckend/pdf_publikasi /Provinsi-Sumatera-Selatan-dalam-Angka-2017.pdf

2. Chayanov, A.V. 1966. The Theory of Peasant Economy (Edited by Daniel Thorner, Basile Kerblay and R.E.F. Smith). Illinois: Homewood

3. Drucker, Peter Ferdinand. 1909. Inovation and entrepreneurship. Sidney Feinberg. New York. ISBN 0-06-091360-6.

4. Duth, Kenneth D. 1979. Principles of management in agribusiness. Reston Publishing Company, Inc. Aprentice-Hall Company. Reston, Virginia. ISBN 0-8359-5595-8.

5. Husin, L dan Lifianthi. 2008. Ekonomi Produksi Pertanian. Fakultas Pertanian Universitas Sriwijaya. Indralaya

6. Putra.I.D.P and W.S. Untari. 2010. Analisis Usahatani Blewa di Desa Demang Kecamatan Besuki [online]. https://unars.ac.id/jurnal/

7. Tiwari, Ak. 2013. Economic growth, energy consumption, financial development, international trade and CO2 emissions in Indonesia. Renewable and Sustainable Energy Reviews Volume 25, September 2013, Pages 109-121

8. Wildayana, E. 2012. The Analyses Structure and Household Income Distribution of Palm Oil (Elaeisguineensis Jacq) Farmers NES-TRANS in South Sumatra, Indonesia. The UMT 11th International Annual Symposium on Sustainability Science and Management, p. 1480-1487, e-ISBN 978-967-5366-93-2. 